\title{
Challenges FACED By STUdent AFFaIRS PRACTITIONERS IN EMBEDDING INDIGENOUS KNOWLEDGE INTO STUDENT LEADERSHIP Development Pedagogy. A CASE for ZimbabWe
}

\author{
Crispen Mazodze ${ }^{1}$ Jacob Mapara $^{2}$ and Maria Tsvere ${ }^{3}$ \\ ${ }^{1}$ Dean of students, Bindura University of Science Education \\ ${ }^{2}$ Director of Institute of Lifelong Learning,.Chinhoyi University of Technology \\ ${ }^{3}$ Chinhoyi University of Technology, Director Academy of Teaching and Learning
}

\begin{abstract}
The drive to mainstream indigenous knowledge into student leadership development in Zimbabwean higher education has recently gained currency. Student leadership development has a Eurocentric historical background and it has continued on this paradigm in the post-independence era. Framed on decolonial theoretical framework this study interrogates the challenges that are faced by student affairs practitioners in their efforts to include indigenous epistemologies into student leadership development programmes. The research was designed as a case study that employed qualitative methods of data collection and analysis focussing on student development practice at three state universities in Zimbabwe namely Bindura University of Science Education, Chinhoyi University of Science Education and Great Zimbabwe University. Data were collected through in-depth interviews with student Affairs practitioners and analysed through NVivo qualitative data analysis software. Research findings indicate that student affairs practitioners face a myriad of problems which hinder the mainstreaming of the knowledge of the local indigenous people into leadership development. These problems include lack of training to empower them with skills to include indigenous epistemologies into student leadership training, lack of funding and policy guidelines. Theorising on this complexity the research recommends the designing of leadership programmes that imbue indigenous epistemologies of the local people in student development such as hunhu/ubuntu values.
\end{abstract}

\section{KEYWORDS}

Student development, Afrocentrism, Eurocentrism, hunhu/ubuntu values, epistemology.

\section{INTRODUCTION}

Student development (SD) in most sub-Saharan African universities is a replica of that of Europe and America and this has prompted the researcher to carry out this study in order to revitalise the zeal to embed indigenous ways of knowing in university co-curricular education. Universities in most sub-Saharan African countries were introduced as direct imports from higher education in the colonial power. Therefore, university structures, the disciplines and co-curricular activities were designed using templates from the west and for some time these universities were affiliated to universities in Britain, France, Portugal and the United States of America. The co-curricular activities are structured and co-ordinated in a similar fashion by the Student Affairs departments. Higher education was introduced to train African elites who would assist in colonial administration. Hence, the academic and co-curriculum was designed to promote Western civilisation at the expense of African culture and indigenous knowledge (Mandew, 2003). As has 
already been alluded to, this resulted in the death of African cultures, epistemologies, values and identities.

This trend has continued after the gaining of political independence due to neo-colonialism and globalisation. Culture is the carrier of a people's moral, ethical and aesthetic values while values are the embodiment of a people's consciousness as a community (Ngugi, 1993; Mapara, 2009). Indigenous knowledge can blended with Western knowledge so as to produce well-rounded graduates (Nicholas-Figueroa et al., 2017). This leads to the production of student leaders who value their African identity, culture, values and languages and who are also relevant to the needs of the global village.

\section{Student DeVElopment in ZimbabWeAn Higher EduCation}

The establishment of the University of Zimbabwe (then University of Rhodesia) as the first institution of higher learning in Zimbabwe was largely based on the British model since it was an affiliate of the University of London (Madambi and Mangena, 2016). As in other HEIs in developing countries, the University College of Rhodesia and Nyasaland (now University of Zimbabwe) was established for the purpose of advancing British colonial and cultural interests. Therefore, the curriculum was designed in a way that ensured the production of graduates who looked down upon African culture and knowledge systems (Mavhunga, 2006). Against this background the Cecil John Rhodes Trust established a scholarship that was meant to promote the creation of an African elite class that was Western in everything except colour. Realising the importance of out of lecture room learning activities the Trust outlined that as a pre-requisite, beneficiaries were expected not only to possess literary excellence but also looked at each applicant's character and social skills. Atkinson cited in Mavhunga (2006), notes that no student would be selected unless he/she showed fondness of sports such as cricket and rugby as well as participating in clubs such as Debate and Toastmasters. The co-curricular activities mentioned above were intended to buttress the notion of the supremacy of British culture in the psyche of beneficiaries (Mavhunga, 2006). It is noteworthy that during the colonial period in Zimbabwe blacks who left the country to study in Britain were regarded as British citizens. This was a deliberate policy to alienate the educated elite from their cultural roots so as to create a class that would be used to perpetuate their interests even after decolonisation.

This same approach has persisted in post- independence Zimbabwe to all would be beneficiaries of the Rhodes scholarship and other British funded scholarships such as the Chevening scholarship. Therefore, students were inculcated with norms and values which were in keeping with the British middle class and there was total disregard for indigenous epistemology as reflected in the curricular practices. The aim was to develop an African exclusive class which looked with disdain on its cultural background and black identity by adopting western values.

Odora- Hopers (2007) notes that Western countries have continued to daggle the carrot of scholarships to students in developing countries as a way controlling the minds of upcoming bureaucrats of these countries. In this regard it is important to note that despite strained political relations between Zimbabwe and Britain, the number of the beneficiaries of the Chevening and Rhodes scholarship has increased over the past few years. The beneficiaries of these scholarships mainly pursuing post-graduate studies are required to undertake their studies in Britain and other countries in the Global North. This illustrates the perpetuation of the Western agenda of domination and exploitation through the creation of a neo-colonial and politically compliant class (Sitwala, 2018). In her definition of the neo-colonial elite, Sitwala (2018) includes the political leadership, members of the judiciary, captains of industry and the businessmen and women as well as religious leaders. These groups of people constitute the leadership of a country 
and hence the significance of epistemic decolonisation in higher education because that is where the national leadership are trained.

From an experiential position the researcher has noted that clubs like Toastmasters and Debate have perpetuated the linguicides, valuecides and epistemicides because the participants are groomed to be models in speaking the 'Queen's language' which is English and exhibiting western values. These clubs promote British middle-class culture because Toastmasters serves to perfect the speaking of the Queen's language while in Debate; the British parliamentary system is used as the model. The fact that the global competitions for these clubs are held in Britain or its two former dominions with predominantly white populations i.e. New Zealand and Australia points to their neo-imperialistic designs.

This type of SD cultivates in students a sense of denial of their cultural heritage, destroys their sense of self pride, identity and consciousness as Africans. To compound the problem most HEIs in Zimbabwe have relegated life and soft skills development to be done informally through the Student Affairs Divisions (SAD). This has resulted in the production of graduates who lack hunhu/ubuntu. The strength of imparting students with their cultural values lies in its capacity to equip students with lifelong communal responsibility and interpersonal relationship as encapsulated in hunhu/ubuntu philosophy. As highlighted above higher education in Zimbabwe is caught within the web of Afrocentrism versus Eurocentrism in SD while at the same time grappling with the effects of neo-liberalism and globalisation.

\section{Policy Context}

Higher education in Zimbabwe is regulated through the Ministry of Higher and Tertiary Education, Innovation, Science and Technology Development (MHTEISTD). The Ministry is championing the shibboleth 'heritage-based education' through which learning, research and innovations as well as student development programmes are expected to be informed by local heritage and knowledge. Student development in most institutions of higher learning in Zimbabwe is treated as an after-thought and is not timetabled. In concurring with this view Madambi and Mangena (2016) expound that student affairs is treated as ancillary and not part of core business of the university. This scenario affects student development negatively in resource allocation because it would not be prioritised in budgetary allocation. Further, there are no written ministerial policies guiding student leadership development in Zimbabwean higher education. At institutional level there are some universities that have policies that relate to SD outlining what type of graduate the university aspires to produce but it seems these policies are rarely implemented. Student affairs practitioners in Zimbabwean universities, particularly Deans of Students need to guide policy formulation concerning leadership, civic, moral and identity development.

The researcher aims to stimulate the development of a leadership frame embedding hunhu/ubuntu core values such as integrity, respect, kindness, courtesy, empathy and decency. The works of Samkange and Samkange cited in Hapanyengwi-Chemhuru and Makuvaza (2014) and Mapara (2009) show that hunhu/ubuntu reveals something about a person's behaviour and moral aptitude and a person with hunhu/ubuntu behaves in a decent, rational and responsible way. Through this study the proffers for a hunhu/ubuntu SD frame that provides a practical template for creating a student leader who has integrity and is morally upright. 


\subsection{Theoretical Considerations}

This study is based on the premise that despite attempts at Africanising higher education curriculum by postcolonial African countries the hegemonic influence of Eurocentrism has remained entrenched. Eurocentrism views the world from a Euro-American lens that advantages Western epistemologies and values while demeaning African ones. It is on the basis of this consideration that this study adopted decoloniality as an appropriate tool to reverse this sad scenario.

The theory underpinning this study draws insights from the scholarly works of Quijano, Maldonado-Torres, Mignolo, Grosfoguel, Smith, Ngugi, Ndlovu-Gatsheni and several other scholars who have theorised on the concept of decoloniality. Further, the works of OdoraHoppers, Nabudere and Mungwini who have problematized on the concepts of cognitive justice and epistemic injustice in knowledge production and legitimation have also enlightened the frame of this study. Decoloniality aims to de-westernise knowledge production and re-position the epistemologies of Africa and other countries of the Global South as the epicentres of knowledge generation in higher education.

The decolonisation agenda of the twenty-first century centres on the destruction and deconstruction of the cognitive empire, which is the colonisation of the mind by the West which has resulted in the killing of the Africans' identities, cultures and knowledge. This calls for the bringing back of indigenous knowledge and cultures into both the academic and co-curricular activities in universities. This view is further advanced by Magubane, cited in Ndlovu-Gatsheni (2018), who proposes that the university in Sub-Saharan Africa originally emerged as a colonial project and disciplines were constituted as forms of colonial knowledge. He further expounds that a transplanted university came with the race poison since most textbooks portrayed Africans as barbarians. Colonialism, imperialism and neo-colonialism have dismembered indigenous peoples because their philosophies and knowledges were declared unfit, evil, primitive and irrelevant for curriculum development (Ngugi, 1997). Ndlovu-Gatsheni (2020, 2015, 2018) argues that coloniality in Africa is a reality because the domains of mind and language have remained colonised. He further posits that coloniality is maintained in books, cultural patterns, self-image, in common sense and aspirations of the youth. This perspective clearly describes the position of SD programmes in higher education in Zimbabwe, where programmes funded by NonGovernmental Organisations (NGOs) are like a culture bomb whose impact is annihilating peoples' belief in their cultures, knowledges and languages. This has resulted in loss of identity amongst students. Therefore, the call to decolonise the university should extend beyond the academic curriculum to include SD.

This study dovetails well into the decoloniality movement regionally and globally. At the global level leading scholars in the struggle against coloniality, neo-colonialism and globalisation such as Grosfoguel (2013), Maldonado-Torres (2019), Mignolo (2013), Ndlovu-Gatsheni (2021), to mention just a few, articulate decolonisation as a challenge against the Eurocentricity of 'being' in order to restore the ontological being of the colonised people. At continental level the African Union (AU) advocates for an African political renaissance that leads to African solutions to African problems as way of challenging global coloniality of power on African economies. African scholars who support the African Union initiative argue that decoloniality is the fitting methodology to free Africans from European hegemony in knowledge production and reproduction. They argue that the consumption of education modelled on Western templates has maintained the mental colonisation of Africans well after gaining political independence. 
The university is an epistemic site of contestation that needs to be decolonised due to its lack of non-Eurocentric ways of knowing and comprehension that guide the production of knowledge (Mbembe, 2016; Magoqwana, 2018; Ndlovu-Gatsheni, 2018). Epistemic freedom will bring to finality the unfinished business of decolonisation by granting Africans the right to think and theorise on equal footing with the West thereby and hopefully creating a new humanity where there is co-existence of knowledges (Ndlovu-Gatsheni, 2018).

As explained earlier, the contemporary university in Africa has faced criticism of having been birthed out of a neo-liberal tradition that suppressed indigenous knowledge in the academy as well as in the co and extra-curricular activities. Literature on decolonising the university so far has not included research focussing on whether decolonial strategies have been adopted by Student Affairs practitioners and how this inclusion or exclusion is impacting on graduates' affective attributes. Decolonising the African university implies challenging Eurocentric epistemologies with the aim of creating an ecological co-existence between African and Eurocentric ways of knowing (Ndlovu-Gatsheni, 2018). From this ecological integration of epistemologies there emerges a new transformative frame and praxis in curricular and cocurricular student leadership development programmes.

\section{Methodology}

This research was envisioned to explore student development which is complex phenomenon that elicit rich and textured explanations, therefore qualitative research approaches were deemed ideal for the study. Qualitative research methods allow for inductive and naturalistic interpretations (Cohen, Manion and Morrison, 2007). Deans of Students, Directors of Campus and Off Campus and Student Development, Counsellors and Wardens were interviewed for data collection in this study. The researcher purposively selected participants according to their position and job functions in the student affairs department. The SAPs participants were selected on the basis of the relevance of their job description to the area under study. Therefore, not all student affairs practitioners (SAPs) were selected. The researcher targeted sections in the student affairs department that were responsible for student development programmes such as campus/ off campus life, counselling, student development and student governance. The researcher applied in- depth interview format for SAPs to create space for discussion while keeping attention on the emerging themes (Cohen, Manion and Morrison, 2007). Due to the coronavirus crisis seven interviews with SAPs were held using Zoom platform.

\section{RESEARCH FINDINGS AND DiSCUSSION}

The findings and analysis revealed that most of the SAPs were not including African indigenous epistemologies into their student leadership programmes. It was also noted that little attention was being paid on the need to put into consideration social identities which were hegemonic in student development. The analysis also exposed that there was over-dependence on the Eurocentric canon of student leadership training discourse.

\subsection{Challenges Hindering Mainstreaming of Indigenous Knowledge into SD Practice}

Student Affairs practitioners were also probed on the challenges that they faced which stifled their efforts to include indigenous knowledge into student development practice. It emerged that A, B, E, G, H and L elaborated that lack of time negatively impacted student development programming since the timetable was congested with academic curricula activities. Participant $G$ explicitly summed up the position indicating that; 
International Journal of Education (IJE) Vol.9, No.3, September 2021

Student development programmes are given enough recognition therefore they are not catered for on the timetable. So, we are forced to do student development programmes after hours. Students will be tired and some who stay out of campus would have left campus.

This kills innovation and resultantly SAPs will be forced to do what they are familiar with, namely clubs and activities that are laden with Eurocentric epistemology. As such institutional timetables should be planned in a way that recognises the importance of these programmes. Such recognition would provide SD with space for African indigenous epistemologies and policies to be heard on campus.

The dearth of literature on student development that presents a non-Eurocentric understanding of $\mathrm{SD}$ is a major stumbling block to the adoption of a decolonial approach. There are very few books or journals that decolonial approach to SD programming. Participant A clearly articulated the problem explaining that:

Theories and models that form the bedrock of SD canon are Eurocentric and African indigenous epistemologies are not represented in that canon.

Participant $\mathrm{C}$ concurred with this view elaborating that:

Non-Western epistemologies are absent in our practice of student development because most books and journal are edited and published in the West. Even our own academics are Western trained hence their scope is Western oriented.

According to Ndlovu-Gatsheni (2020) the West has been able to reproduce itself in the Global South through the elite bourgeoisie class that also includes academics and institutions such as universities. This class is geographically and socially located in the Global South but they think epistemically like the West and the university promotion system aligns them to the Eurocentric knowledge production and legitimation system. Ndlovu-Gatsheni (2020) further expounds that literary works by academics from the Global South are aligned to the Eurocentric frame of reference that orients them to conformity to Western systems that alienates knowledges from the subaltern. This rigid Western system makes it hard to accept non- Eurocentric knowledge.

The study enquired the extent to which universities funded SD programs from the SAPs. Their responses were classified under the greater extent and lesser extent codes, from which a comparative diagram was extracted. All the SAPs highlighted that universities funded SD programmes to a lesser extent.

This created a big problem for SAPs because lack of funding negatively affects the implementation of SD activities. Lack of funding opens a gap which is usually filled by external stake holders such as corporates and NGOs who come with their own agendas which may not be compatible with the values of indigenous people. 


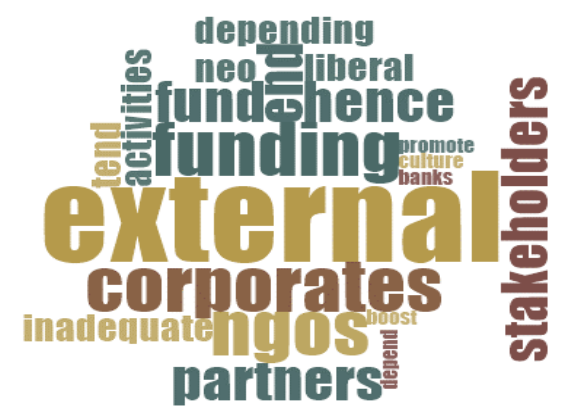

Word cloud of SAPs verbatim responses on SD funding

The above scenario reflects that poor funding of student development programmes was cited as a major stumbling block to the inclusion of African indigenous epistemologies into SD. External stakeholders who partnered Student Affairs departments through funding some SD programmes tended to dictate the nature of the activities they preferred to fund. This explains why Western oriented clubs are flourishing on campuses. Both SAPs and students' leaders concurred on the observation that pro-Eurocentric clubs were popular on campuses. SAPs indicated that some of their programmes promoted behaviour which is against societal expectations. Participant B explained that:

Yes, but to a very little extent. We do depend mainly on external stakeholders such as SAYWHAT, Boost-Enactus, Banks, Corporates and NGOs such as female student Network, Padare, Junior Chamber International. SD is not valued much and it is not timetabled and it is left to be done informally, hence this gap is filled by external stakeholders, who come with their own agenda and they only fund activities that meet the requirements.

This view was supported by participant $\mathrm{D}$ who stated that:

Student Development is not seriously regarded, hence funding is just too little. Further, SD is not timetabled therefore programmes are not usually budgeted for. So, we end up depending on external partners e.g. Banks, Corporates and NGOs who fund some club activities. This is good but it takes away our power to decide which programmes they should fund as they come with their own agendas. Their literature is Eurocentric and they strive to produce leaders who are programmed to support Eurocentric views and perspectives.

A closer analysis of these two participants' views shows that external funding is used to mask the real problem which is the status which student development is afforded by the executive management at the institutions of higher learning. SD is treated as none core business of the university hence it is not budgeted for nor timetabled. If SD is to achieve its core function of producing well-rounded graduates then the prevailing scenario at most universities has to be changed. Decolonisation of SD may not be successfully undertaken if its practice and survival remains at the mercy of corporates and NGOs who promote a neo-liberal agenda. Further, mainstreaming of African indigenous knowledge into SD programmes cannot be expected to happen when these programmes are surviving on handouts from organisations that promote a Eurocentric ideology.

The other problem that has been highlighted is cultural ambivalence faced by students mainly from rural backgrounds when they come to universities. They are exposed to programmes which Participant D described as promoting promiscuity especially the free distribution and lessons on use of condoms and morning after pills. 
Participant H lamented that:

We have a levy for SD programmes, however it is inadequate and we end up depending on our partners like Banks, SAYWHAT, National Aids Council, Higherlife Foundation, BoostEnactus but the problem is that they tend to fund programmes that are in line with their interests which are neo-liberal. For example Funding for $S D$ is very small, For example some our partners emphasise the use of condoms and morning after pills.

This may be interpreted as encouraging promiscuity while in African culture youths are encouraged to refrain from sexual activities before marriage. This cultural incompatibility affects students from rural areas mainly because back home their parents expect them to shun away from sexual activities. Therefore, mainstreaming African indigenous knowledge into leadership development is essential in order to open its theory beyond Eurocentric epistemology.

\subsection{Deficiency in SAPs 'Educational Training and Professional Development}

Nine out of twelve of the SAPs i.e. C, D, E, G, H, I, K and L expressed that their educational and professional training prepared them for their job as student development practitioners. However, an analysis of their responses on issues relating to decoloniality shows that they were still to comprehend what decolonisation entails. Lack of training of practitioners is a serious challenge that impedes the decolonisation agenda in their practice. Therefore, to facilitate the implementation of a decolonial approach in student development, the student Affairs practitioners need to undergo a paradigm shift in epistemic cognition. Epistemic cognition relates to the way practitioners acquire, comprehend and use knowledge (Ndlovu-Gatsheni, 2020; 2018). Thus there is need to expose practitioners to decolonial thinking as this may trigger an awareness in their thought processes for the need of a new SD epistemology. Eurocentric hegemony is a significant barrier to the inclusion of African indigenous knowledge into leadership development in higher education.

\section{Coloniality of Language}

A word cloud of the SAPs' verbatim responses to the enquiry on the language of instruction in SD programs at their universities was extracted. The top theme that emerged shows that in English is the dominant pedagogical language while Shona, Ndebele and other indigenous languages are marginalised.

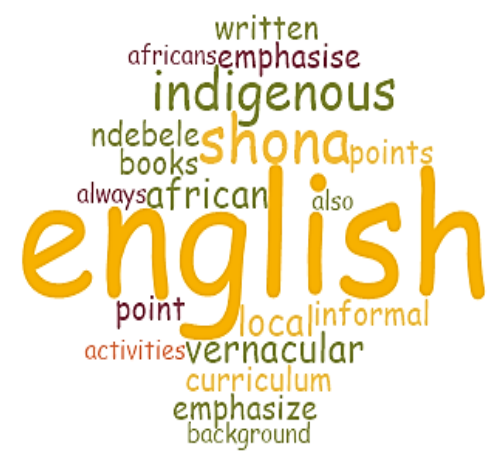

Word cloud the dominance of English language 
English emerged as the most discussed word by the practitioners. The use of English as the sole language of instruction is justified on the ground that it increases students; epistemic access and ultimately success. Yet the reality is that colonial languages played a big role in creating knowledge frameworks that rationalised the displacement of local languages in the curriculum (Kerfoot, 2021). .

Participant's response indicates that though Shona and other local indigenous languages are marginalised, they are the default mode which SAPs use to emphasise or clarify points. This point is quite significant because indigenous languages are carriers of traditional culture and it is high time that they are recognised as languages of pedagogy in higher education institutions (Nicholas-Figueroa et al., 2017). Use of local languages also help in stemming linguicides that is the killing of indigenous languages due to hegemonic influence of Eurocentrism which imposes linguistic dependency on European languages in teaching and research.

Participant D concurred with this view saying:

The language of instruction is English although sometimes we use Shona and Ndebele, to emphasize a point. The literature that we use, the theories and models are all in English.

While Participant D agrees with Participant B on the use of local languages to stress a point, what can also be discerned from her explanation is that there is need for African academics to produce theories and literature on student development that is informed by indigenous epistemologies and policies. Hountongji (1990) cited in Ndlovu-Gatsheni (2021) expounds that there is need for African higher education to delink itself from dependence on Western foreign libraries and documentation centres for information. This call is important due to the fact that for decolonial pedagogy of SD to succeed there is need to reduce importation of theories and models from the West. In the same vein, Smith (1999) warns that one cannot destroy the master's workshop using the master's tools. This implies that mainstreaming of African indigenous epistemologies cannot be successful implanted using foreign languages and theories.

This prevailing situation is harmful to the survival of indigenous culture because death of a language results in the death of culture since language is a carrier of culture. As argued above this situation needs to be addressed at policy level. This is mainly because institutional policies are the ones directing that English must be the language of instruction and this creates a challenge to SAPs as well as to academics in delivering their lectures. There are situations when academics also turn to local languages in their efforts to help learners understand difficult concepts. This study advocates for the prioritisation of local languages for pedagogical purposes on equal footing with Western languages.

\subsection{Absence of Policies to Guide Student Development}

Student development is an area of epistemic and cultural contestation. The debate is whose epistemologies, ontologies and cultural values should be deemed authoritative in student development programming. Due to coloniality Eurocentric patterns of power and systems of knowledge, Western epistemologies and ontologies have continued to exert hegemonic control on higher education in Sub-Saharan Africa (Kerfoot, 2021).

The SAPs were initially asked if the MHTEISTD had a policy on SD. Their responses were classified into ministerial policy available and no ministerial policy codes. 
International Journal of Education (IJE) Vol.9, No.3, September 2021

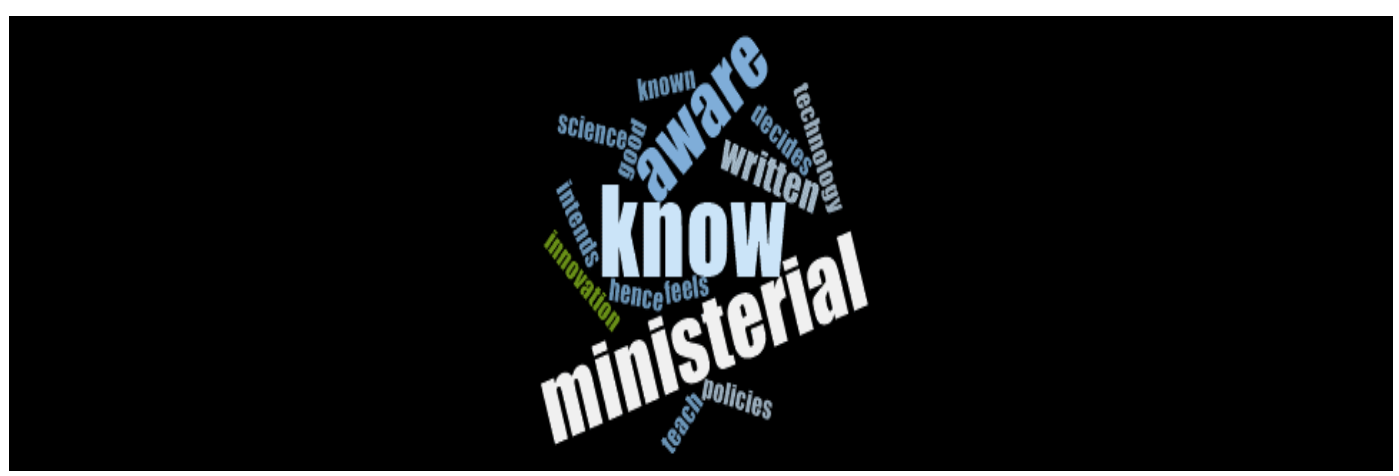

Fig.6.9 Word on SD policies.

The participants expressed that there were no clearly defined institutional policies on student development at their universities. They also indicate that institution guidelines on SD were immersed in several key documents of the university such as strategic plans and ordinances that govern student conduct and discipline. Practitioners explained that they used these institutional documents as guidelines to leadership programming.

Participant F explicated that:

At institutional level we do not have a specific policy on SD but it is embedded in other documents and structures in the University e.g. Ordinance number 2 tries to foster the moulding of a morally upright person.

In the same breadth Participant $\mathrm{H}$ confirmed that:

I am not aware of any Ministerial policies and at institutional level, we do not have a clearly defined and written policy. However, in other university documents such as the mission statements and ordinances on residence life there is emphasis on holistic development of the student with humane values such as integrity, togetherness.

Generally, SAPs are implementing SD in a context of policy vacuum save at one university where three SAPs from the institution indicated that there was a policy drawn at the institution to provide a frame to guide SD.

\section{CONClusion}

This chapter highlighted the challenges faced by SAPs in the struggle to decolonise SD programmes. These challenges, inter-alia included lack of funding, lack of space on the institutional timetable, paucity of literature by local authors and deficiency of skills on decolonisation by SAPs. Failure to fund SD by universities exposes them to neo-colonial manipulation by corporate organisations that partner SAPs through funding some programmes especially those which advance the interests of coloniality. The non- provision of space for SD programmes on the timetable results in students not treating SD seriously. Lack of training in decolonisation strategies and non-availability of literature or theories on SD by African indigenous theorists was also cited as major challenges which lead to continued hegemony of Eurocentrism on student development. The marginalisation of indigenous languages poses a major threat to the mainstreaming of indigenous epistemologies in student development because decolonisation cannot be effectively executed using the languages of the imperial powers. The 
need for a policy framework to guide the planning and implementation of SD was highlighted as an important step in creating an enabling environment to embed indigenous knowledge.

\section{REFERENCES}

[1] Cohen, Louis, M. L. \&, \& Morrison, K. (2007). - by Louis Cohen, Lawrence Manion and Keith Morrison. In Resaerch nMethods in Education (Vol. 55, Issue 4). https://doi.org/10.1111/j.14678527.2007.00388_4.x

[2] Cresswell, J. W. (2009). Research Design: Qualitative, Quantitative and Mixed Methods Approaches (3rd Editio). SAGE.

[3] Dugan, J. P. (2006). Involvement and leadership: A descriptive analysis of socially responsible leadership. Journal of College Student Development, 47(3), 335-343. https://doi.org/10.1353/csd.2006.0028

[4] Dugan, \& Komives. (2007). Developing leadership capacity in college students: Findings from a national study. A Report from the Multi-Institutional Study of Leadership. Developing Leadership in College Students: Finding from a National Study, April, 1-28. http://mslreviewteam.wiki.usfca.edu/file/view/MSLReport+06.pdf

[5] Eddy, J., \& Murphy, S. D. (2000). International higher education systems. SAGE.

[6] Etieyibo, E. (2017). Moral education , ubuntu and ubuntu-inspired communities. 0136. https://doi.org/10.1080/02580136.2017.1269995

[7] Evans, JN.J.;Forney, D.S., Guido, F.M., Patton, L.D. \& Kenn, K. A. (2010). Student Development in College: Theory ,Research and Practice (2nd ed.). Jossey-Bass. https://doi.org/10.1192/bjp.112.483.211-a

[8] Grosfoguel, R. (2003). Introduction: Geopolitics of Knowledge and Coloniality of Power: Thinking Puerto Rico and Puerto Ricans from the Colonial Difference. In Colonial Subjects: Puerto Ricans in a Global Perspective.

[9] Grosfoguel, R. (2013). The Structure of Knowledge in Westernized Universities : Epistemic Racism / Sexism and the Four Genocides / Epistemicides of the Long 16th Century. 11(1).

[10] Japhet, L., \& Usman, T. (2013). The use of grounded theory technique as a practical tool for qualitative data collection and analysis. Electronic Journal of Business Research Methods, 11(1), 2940.

[11] Komives, S. R., Mainella, F. C., Longerbeam, S. D., Osteen, L., \& Owen, J. E. (2006). A leadership identity development model: Applications from a grounded theory. Journal of College Student Development, 47(4), 401-418.

[12] Kuh, G. D., Cruce, T. M., Shoup, R., Kinzie, J., \& Gonyea, R. M. (2008). Unmasking the effects of student engagement on first-year college grades and persistence. Journal of Higher Education, 79(5), 540-563. https://doi.org/10.1353/jhe.0.0019

[13] Kuh, G. D., Kinzie, J., Buckley, J. A., Bridges, B. K., \& Hayek, J. C. (2006). What Matters to Student Success : A Review of the Literature, National Postsecondary Education Cooperative. July.

[14] Lewis, S. (2015). Qualitative Inquiry and Research Design: Choosing Among Five Approaches. In Health Promotion Practice (Vol. 16, Issue 4). https://doi.org/10.1177/1524839915580941

[15] Long, D. (2012a). The foundations of student affairs: A guide to the profession. Environments for Student Growth and Development: Librarians and Student Affairs in Collaboration, 1-39. http://ir.library.illinoisstate.edu/fpml\%0Ahttp://ir.library.illinoisstate.edu/cgi/viewcontent.cgi?article= $1028 \&$ context $=\mathrm{fpml}$

[16] Long, D. (2012b). Theories and Models of Student Development. Environments for Student Growth and Development, 41-55. https://ir.library.illinoisstate.edu/fpml

[17] Madambi, M \& Mangena, F. (2016). Challenges Facing Student Affairs Practitioners in Zimbabwe:The Call For a Higher Education Meta-Normative Framework. Journal of Educational Research, 28(1), 61-78. https://doi.org/10.14426/jsaa.v2i1.56

[18] Maldonado-Torres, N. (2017). Frantz Fanon and the decolonial turn in psychology: from modern / colonial methods to the decolonial attitude. 47(4), $432-441$. https://doi.org/10.1177/0081246317737918

[19] Mamdani, M. (2016). Inter-Asia Cultural Studies Between the public intellectual and the scholar: decolonization and some post-independence initiatives in African higher education. 9373. https://doi.org/10.1080/14649373.2016.1140260 
[20] Mandew, M. (2003). A Guide to Student Services in South Africa, Pretoria. CHET.

[21] Mapara.J. (2013). Ngano: A Platform for the dissemination of Ubuntu/Unhu values. In J. \& Mapara \& B. Mudzanire (Eds.), Ubuntu/Unhu Philosophy: A Brief Shona Perspective (pp. 99-124). Bhabhu Books.

[22] Mapara, J. (2009). Indigenous Knowledge Systems in Zimbabwe: Juxtaposing Postcolonial Theory. Journal of Pan African Studies, 3(1), 139.

[23] Mavhunga, P. J. (2006). Africanising the school curriculum: A case for Zimbabwe. Zimbabwe Journal of Educational Research, 18(3).

[24] Mbembe, A. (2016a). Decolonizing the university: New directions. Arts \& Humanities in Higher Education, 15(1), 29-45. https://doi.org/10.1177/1474022215618513

[25] Mignolo, W. (2013). Geopolitics of sensing and knowing: On (de)coloniality, border thinking, and epistemic disobedience. 1(1), 129-150. https://doi.org/10.3384/confero.2001-4562.13v1i1129

[26] Mungwini, P. (2017). “African Know Thyself”: Epistemic Injustice and the Quest for Liberative Knowledge. International Journal of African Renaissance Studies, 12(2), 5-18. https://doi.org/10.1080/18186874.2017.1392125

[27] Nabudere, D. W. (2007). Towards an Afrokology of knowledge production and African regeneration. International Journal of African Renaissance Studies - Multi-, Inter- and Transdisciplinarity, 1(1), 7 32. https://doi.org/10.1080/18186870608529704

[28] Nicholas-Figuera, L., Wall, D., Van Muellen, M \& Duff, L. (2017) Implementing Indigenous Knowledge in western Science Educational Systems and Science Research on Alaska's North Slope. International Journal of educationvol.9 (4) 15-36

[29] Ndlovu-Gatsheni, Sabelo J. (2018). Epistemic Freedom in Africa:Deprovincialisation and Decolonisation. Routledge.

[30] Ndlovu-Gatsheni, Sabelo J. (2021). Beyond Coloniality of Internationalism. International Relations, $1-8$.

[31] Ndlovu-Gatsheni, Sabelo J. (2015). Global Coloniality and the Challenges of Creating African Futures. Strategic Review for Southern Africa, 36(2), 181-202.

[32] Ndlovu-Gatsheni, Sabelo J. (2018). The dynamics of epistemological decolonisation in the 21st century: Towards epistemic freedom. Strategic Review for Southern Africa, 40(1), 16-46.

[33] Ndlovu-Gatsheni, Sabelo J. (2021). Why has Europe's Past become Africa's Postcolonial Present? Reflections on Mahmood Mamdani's ideas on decolonising the Political Community. CODESIRIA Bulleti Online, 12(2-3), 1-7. https://doi.org/10.1016/s0167-0115(01)00338-x

[34] Ngugi wa Thiong'o. (1992). Moving the centre: the struggle for cultural freedoms. In Studies in African literature. https://doi.org/10.1177/002198949102600116

[35] Odora Hoppers, C. A. (2007). The Centre-periphery in Knowledge Production in the Twenty-first Century. Compare: A Journal of Comparative and International Education, 30(3), 283-291. https://doi.org/10.1080/713657471

[36] Sitwala, J. N. (2018). Ngugi's Portrayal of neo-colonial elitism and its influence in Kenya in his postcolonial novels.

[37] Smith, L. H. (2019). Epistemic decolonialityAs a pedagogical movement in Social Work: A turn of Theory to Anti-Colonial Theorists. Critical Social Work, 1(May), 1-20 